\title{
The Information Support System's Formation of Marketing Innovative Decisions in Ukrainian Companies
}

\author{
Illiashenko Sergii, Shypulina Yuliia, Gryshchenko Olena, Illiashenko Nataliia
}

\begin{abstract}
Nowadays the main strategic goal of companies can be described as the improvement of the efficiency in order to achieve higher profitability. Under these circumstances, information systems and technologies should be considered as key tools that allow to achieve higher levels of business efficiency and productivity. They allow businesses to create new products and services, as well as brand new business models. Innovations in ICT and management information systems have led to significant changes in managerial methods, processes and vision.

The aim of the research is the development and justification of theoretical and methodological foundations of the information support system's formation for marketing innovative decisions. The comparative and statistical analysis, method of generalization, system and structural analysis, structural and logical modeling, fundamentals of marketing and management, scientific findings devoted to the study of information support of decision-making were used to achieve the goals of the study.

As a result, the authors have developed the principles of forming an information support system for marketing innovative decisions in Ukrainian companies. The functions, marketing information system's structure and its components interactions, sequence and content of stages of MID development and creation, information flows interactions scheme are developed.

The research results contribute to the theoretical and practical principles of innovation management in terms of increasing the level of information support for marketing innovative decisions in Ukrainian companies.
\end{abstract}

Keywords : Information support system; Marketing innovative decisions; Decision making; Information support; Information flows.

\section{INTRODUCTION}

The current state of the global economy is characterized by permanent instability that triggered the start of changing technological structures (from $5^{\text {th }}$ to $6^{\text {th }}$ ) and launching new (the $4^{\text {th }}$ ) Industrial Revolution. Constant changes in business conditions reduce the effectiveness of traditional methods of

Revised Version Manuscript Received on October 15, 2019.

Illiashenko Sergii, Department of Management of Innovative Entrepreneurship and International Economic Relations, National Technical University "Kharkiv Polytechnic Institute", Kharkiv, Ukraine; Department of Marketing, University of Economics and Humanities, Bielsko-Biala, Poland.( Email: illiashenko.s@gmail.com)

Shypulina Yuliia, Department of Economic Cybernetics and Marketing Management, National Technical University "Kharkiv Polytechnic Institute”, Kharkiv, Ukraine. (Email: shypulina.j@gmail.com)

Gryshchenko Olena, Department of Business Economics and Administration, Sumy State Pedagogical University, Sumy, Ukraine. (Email: elena.gryshchenko@gmail.com)

Illiashenko Nataliia, Department of Economic Cybernetics and Marketing Management, National Technical University "Kharkiv Polytechnic Institute", Kharkiv, Ukraine. (Email: nat.illiashenko@gmail.com) market-oriented business activity: innovation, production, marketing, personnel, finance, etc. Among these methods, as evidenced by practice, the crucial role have innovations and marketing. Reduced effectiveness of traditional marketing tools initiates search for new approaches to marketing activities that would take into account the current realities of socio-economic processes (globalization, the mixing of cultures, the formation of global market knowledge, etc.), new opportunities caused by active implementation of ICT, human's activity informatization, etc. This would increase the effectiveness of marketing innovative decisions (in particular when considering new market opportunities and threats, target markets, changing consumer behavior, etc.), would enable specific businesses to develop competitive advantages, increase competitiveness and strengthen their market positions. Experience shows that decisions, especially innovative ones, are effective if the decision-maker has as complete information as possible and can predict the possible consequences. Accordingly, the problem of information support for marketing innovative decisions is becoming exacerbated.

The literature review has shown that studies of numerous researchers deal with issue of information support of management activity. Among them are Cox D.F. \& Good R.E. [3], Graf F. [4], Li E.Y. [5], Proctor R.A. [6], Samli A. Coskun [7], Sisodia R.S. [8], Talvinen J.M. [9], López-Bonilla J.M. López-Bonilla L.M. \& Peña-Vinces J.C. [10], Daneshjo N. \& Kravec M. [11], Hakimpoor H. \& Khairabadi M. [12], Laudon K.C. \& Laudon J.P. [13], Al-Mamary Y.H., Shamsuddin A. \& Aziati N. [14], Abrego-Almazán D., Sánchez Tovar Y., Medina Quintero J. [15]. They examine the information system in general and the management information support in particular as a prerequisite for effective management, and note the close relationship between the management process and information flows.

For instance, Hakimpoor \& Khairabadi [12] have provided the research on impact of using management information systems and conceptual dimensions of information quality on the quality of managerial decisions. Based on the neural network analysis, they state MIS as an important factor that had significant contributory effect on the decision making.

Al-Mamary, Shamsuddin, \& Aziati [14] have performed the literature review of technology adoption and information

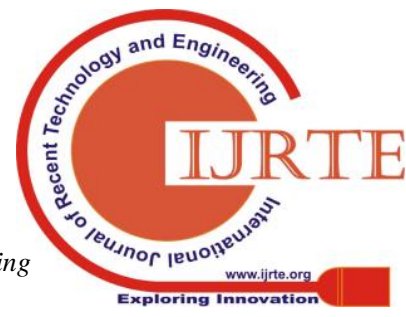


system success in managerial decision making. Researchers have proposed theoretical model which consists of six variables (components): management information system quality, information quality, top management support, perceived usefulness, decision makers' satisfaction and quality of managerial decision making

In [15] researchers emphasize that information system designers have to address the needs of the end users and make full use of the completeness, security, availability, speed, and accuracy of the information to increase user satisfaction, but specially to improve the intention of use-utility of the system.

In [11] the sources of marketing information system are investigated and basic division of data sources is provided. Researchers indicate that sharp increase in information requirements is currently sufficiently supplied with new, high efficiency, information technology.

However, despite the numerous theoretical, methodological and applied research, the issues of information support to the process of developing and making marketing innovative decisions remain insufficiently studied. Particular attention should be paid to studying the peculiarities of information systems implementation at Ukrainian enterprises and the distribution of functions of information systems components in the process of developing and implementation of marketing innovative decisions (MID).

\section{RESEARCH OBJECTIVE AND METHODOLOGY}

This article focuses on problems related to development and justification of theoretical and methodological foundations of the information support system's formation for marketing innovative decisions. This, in turn, will allow to enhance the efficiency of their economic activity in terms of creating new values at different levels and in different industries.

The methodological framework of the study is the comparative and statistical analysis, method of generalization, system and structural analysis, structural and logical modeling, fundamentals of marketing and management, scientific findings devoted to the study of information support of decision-making.

\section{RESEARCH RESULTS}

Business entities are constantly striving to improve the efficiency of their activities in order to achieve higher profitability. Under these circumstances, information systems and technologies should be considered as one of the most important tools that allow to achieve higher levels of business efficiency and productivity, especially in terms of constant changes in business climate and management culture.

Information systems and technologies are the main tools that allow businesses to create new products and services, as well as brand new business models. Developments in information and communications technology (ICT) and management information systems have led to significant changes in production methods and forms of employment.

So, according to Eurostat [16], the total value added of the
EU's ICT sector was just over EUR 580 billion in 2016. Moreover, the ICT sector was equivalent to $3.75 \%$ of the EU's GDP.

According to [17] the ICT sector of the 40 economies has tripled in value added in 2 decades (namely, 1995-2014). Our observations show that the growth rate of the sector will increase in the future and may show increase by four to five times. This is especially relevant for Ukrainian companies that have been actively investing in information technology in recent years. To date, however, the share of companies that hired specialists in ICT is quite small and is about $5 \%$. According to the State Statistics Service of Ukraine [18], in 2018 the volume of investments of Ukrainian companies in the intangible assets (namely software and databases) that form the basis of ICT amounted to 9476,4 million UAH ( $+238 \%$ compared to 2010). A survey of business executives makes it possible to conclude that in the last 5-7 years considerable funds have also been invested in information storage systems and data protection. However, it should be noted that the State Statistics Service of Ukraine does not provide data collection in this context.

The study of economic information systems' evolution. The information support of the process of development, adoption and implementation of marketing innovative decisions (DAIMID) depends on the means and sources of its formation. While providing a business processes company can use data sources which are both inside and outside the entity.

The DAIMID process uses information from three sources:

1.Experience (internal data covering the results of a particular set of company's management parameters: production volume, cost volume, inventory, sales dynamics, cash flow dynamics and trends, accounts receivable and payables etc. Information that is regularly published and updated on events occurring in the external environment);

2.Research (specially organized marketing researches on investigated problems);

3.Expertise (consulting, interviewing of internal and external independent experts. It is also possible to use computer-based information systems).

It should also be noted that information support of business couldn't be accomplished without building an appropriate marketing information system (MkIS). Implementation of such information systems assists to solve not only basic economic problems, but also to carry out a deeper analysis, such as determining consumer priorities and requests, identifying future strategic actions, determining market trends, and, as a result, more informed decision-making resulting in positive impacts to the company's competitiveness.

Economic information system - a set of internal and external information flows and feedback flows of an economic object, methods, tools, specialists involved in the process of information processing and decision-making [2, c. 160].

Based on [2;9] analysis we have identified the following major stages in the evolution of economic information systems (see Figure 1). 
The evolutionary process does not end at this stage, and undoubtedly, new trends in the functioning of the business environment will lead in the future to the modification of existing or the emergence of fundamentally new information systems. Thus, one of the likely direction of development is a system that will use artificial intelligence. It should be noted that today there are considerable debates about the feasibility and safety of using artificial intelligence. On the one hand, there is an vision of the impossibility of replacing the human mental capacity and ability to judge, on the other hand - more attention is paid to the prospects of artificial intelligence in combination with information and communication technologies.

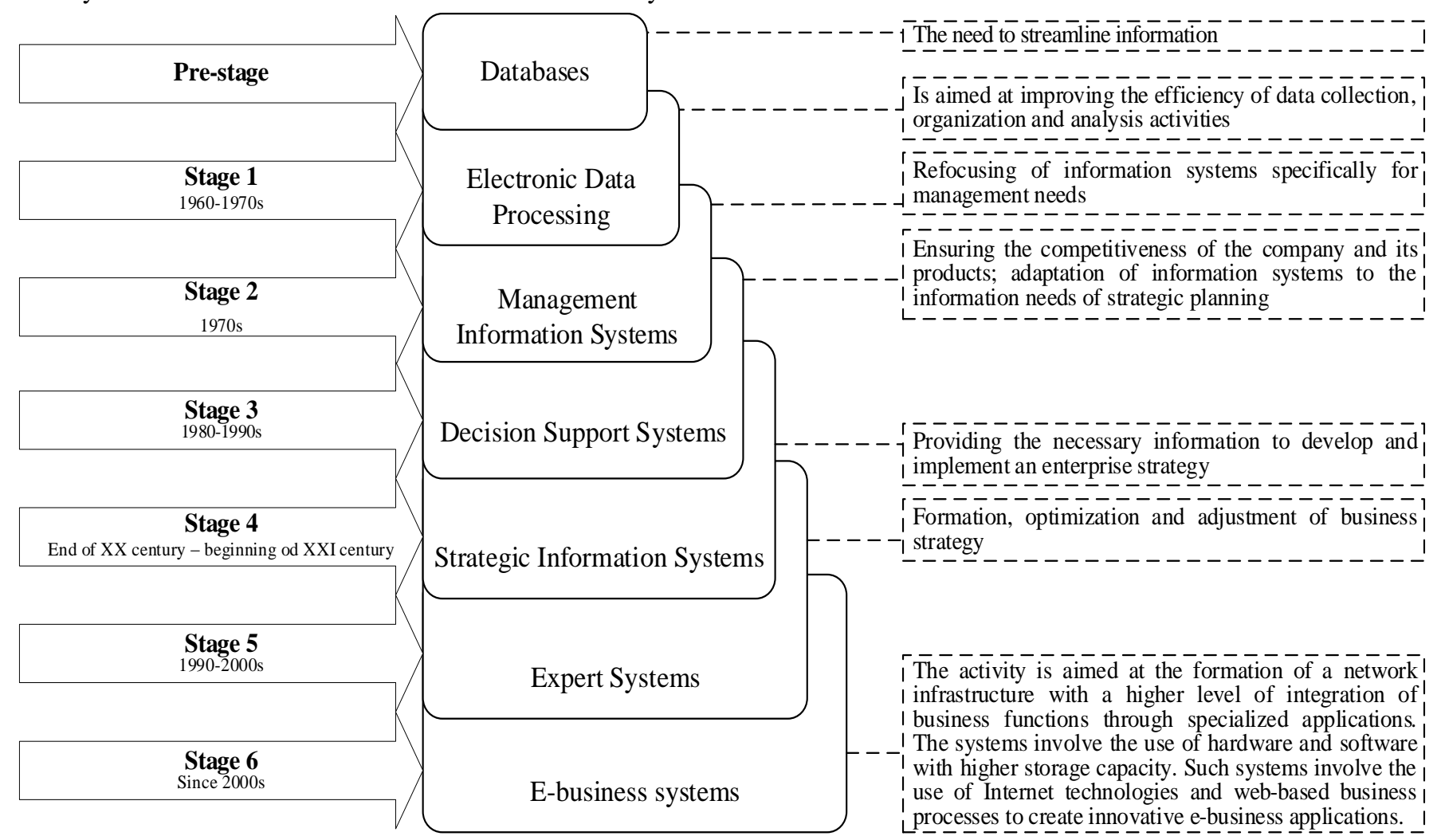

Fig. 1. Key stages of economic information systems' evolution

Comparative analysis of information systems on the different stages of development is presented in Table 1.

In addition, the marketing information system (MkIS) becomes one of the key elements of DAIMID process and greatly affects the efficiency and quality of MID.

MkIS traditionally seen as a set of procedures and methods of analysis and presentation of information for its use in marketing decision-making [9].

It should be noted that companies need to create MkIS due to the following reasons:

- strengthening and developing business relations;

- development of modern means of communication;

- turnover growth;

- rapid development of trade;

- increased competition;

- saturation of markets with goods;

- development and complication of marketing and business activities.

The information support system's structure formation. The company's MkIS structure should take into account the specifics of its activities. We believe that the DAIMID process best meets the functional approach. It should be noted that today many researchers have developed their own models of marketing information systems based on a functional approach (see Table 2).

During DAIMID process MkIS components perform the following functions (see Table 3):
1) collecting data on various subjects and from different sources (F1);

2) data analysis and systematization of information related to particular issues (F2);

3 ) information storage and accumulation (F3);

4) forecasting performance of the company, identifying promising areas for development, identifying potential problems and limitations of economic activities, etc. (F4);

5) marketing activities control and monitoring of current management indicators within the company (F5);

6) marketing activities control of the company in the external environment and monitoring the effectiveness of implemented marketing instruments and decisions (F6);

7) information support of the decision-maker (F7).

To sum it up, the main tasks of MkIS functioning at company's management system are the following:

- monitoring and support of information flows between marketing department, other departments of the company and external environment;

- monitoring the performance indicators of the company and assessment of opportunities and threats to further business activities;

- collecting, accumulating and analyzing information to predict possible strategic 
actions and to generate marketing decisions;

- the decision-maker information support.

DAIMID process stages have specific information needs. For example, Figure 2 explores the nature of the information provided by MkIS, identifies threats to decision-making, and suggests ways to overcome such threats.
The role of marketing information system. Thus, it should be noted that MkIS can be an important tool for conducting business activities (including innovative activities) of a company and provide a number of competitive advantages, namely

Table 1: Comparative analysis of development stages of business-purpose information systems

\begin{tabular}{|c|c|c|c|}
\hline \multirow{2}{*}{ Stage } & \multicolumn{3}{|l|}{ Description } \\
\hline & \multicolumn{2}{|l|}{ Database features } & \multirow{2}{*}{\begin{tabular}{|l|} 
Functions \\
Storage of information. Access to \\
information. The ability to sample data
\end{tabular}} \\
\hline Databases & $\begin{array}{l}\text { An extensive database on } \\
\text { all aspects of business }\end{array}$ & $\begin{array}{l}\text { Archiving and providing } \\
\text { information to the management } \\
\text { process }\end{array}$ & \\
\hline $\begin{array}{l}\text { Electronic Data } \\
\text { Processing }\end{array}$ & $\begin{array}{l}\text { An extensive database on } \\
\text { all aspects of business }\end{array}$ & $\begin{array}{l}\text { Improving the efficiency of } \\
\text { business units to collect data } \\
\text { for business operations }\end{array}$ & $\begin{array}{l}\text { Access to information. Data processing } \\
\text { capability. The ability to sample information }\end{array}$ \\
\hline $\begin{array}{l}\text { Management } \\
\text { Information } \\
\text { Systems }\end{array}$ & $\begin{array}{l}\text { An extensive database on } \\
\text { all aspects of business }\end{array}$ & $\begin{array}{l}\text { Support in all aspects of } \\
\text { management activities }\end{array}$ & $\begin{array}{l}\text { Access to external and internal data. Ability } \\
\text { to sample, update data and delete data }\end{array}$ \\
\hline $\begin{array}{l}\text { Decision Support } \\
\text { Systems }\end{array}$ & $\begin{array}{l}\text { A database for managerial } \\
\text { decision making }\end{array}$ & $\begin{array}{l}\text { To ensure the decision-making } \\
\text { process }\end{array}$ & $\begin{array}{l}\text { Access to external and internal data. Ability } \\
\text { to manipulate data, process and generate } \\
\text { new data. Ability to sample, update and } \\
\text { delete data }\end{array}$ \\
\hline $\begin{array}{l}\text { Strategic } \\
\text { Information } \\
\text { Systems }\end{array}$ & $\begin{array}{l}\text { An extensive database on } \\
\text { all aspects of business }\end{array}$ & Support for strategic planning & $\begin{array}{l}\text { Access to external and internal data. Ability } \\
\text { to manipulate data and make forecasts. } \\
\text { Ability to evaluate the effectiveness of the } \\
\text { enterprise Data control }\end{array}$ \\
\hline Expert Systems & $\begin{array}{l}\text { An in-depth database } \\
\text { highlighting knowledge of } \\
\text { theory, practice and } \\
\text { problem-solving strategies }\end{array}$ & $\begin{array}{l}\text { Formation optimization and } \\
\text { adjustment of business strategy }\end{array}$ & $\begin{array}{l}\text { Access to external and internal data. The } \\
\text { ability to manipulate data and form } \\
\text { strategies. The ability to perform dynamic } \\
\text { tasks, which may change during problem } \\
\text { solving process. Control of data, } \\
\text { establishing their incompleteness and error }\end{array}$ \\
\hline $\begin{array}{l}\text { E-business } \\
\text { Systems }\end{array}$ & $\begin{array}{l}\text { An in-depth database that } \\
\text { maximizes coverage of } \\
\text { business processes and } \\
\text { allows to store large } \\
\text { amounts of information, } \\
\text { quickly exchange and } \\
\text { backup it }\end{array}$ & $\begin{array}{l}\text { Use of Internet technologies } \\
\text { and web-based business } \\
\text { processes to create innovative } \\
\text { e-business applications }\end{array}$ & $\begin{array}{l}\text { Access to external and internal data. Ability } \\
\text { to manipulate data, process and generate } \\
\text { new data. Ability to manage business } \\
\text { processes, multi-objective assessment and } \\
\text { strategic planning. The ability to perform } \\
\text { dynamic tasks, which may change during } \\
\text { problem solving process. Full control and } \\
\text { monitoring. }\end{array}$ \\
\hline
\end{tabular}

Source: Generalized by the authors

- performance and prospects of economic activity (increased levels of decisions validity and significantly reduced risks associated with their implementation etc.)

- company's flexibility and adaptability;

- information security and awareness (knowledge of the market trends and industry development trends, of consumer and competitor behavior, of possible directions of company's development, etc.);

- distribution and implementation of information resources (availability of communication channels and instruments, improved methods of information dissemination, feedback availability, access to analytical tools, etc. );

- development and implementation of innovations.

It is also necessary to note a number of problems in MkIS functioning in Ukrainian companies:

1. Lack of understanding of management information needs by ICT and information support professionals and, as a consequence, the implementation of inadequate information support, wrong choice of managerial actions and financial losses;

2. Low level of managers involvement to MkIS organization and functioning;

3. Pure use of computer systems capabilities, which in some cases results in low levels of data processing and interpretation;

4. Human factor when entering and processing information;

5. Personnel distrust of information content and quality. This is based on the fact that MkIS inherent transmission failures, distortions, and incorrect interpretation of information;

6. The possibility of loss or stealing of information;

7. MkIS staff access failures due to technical, software bugs and infrastructure constraints. 
Table 2: Systematization of approaches to company's MkIS structure

\begin{tabular}{|c|c|}
\hline $\mathrm{r}(\mathrm{s})$ & ponents \\
\hline $\begin{array}{l}\text { Kotler Ph., } \\
\text { Armstrong } \\
\text { G. [1] }\end{array}$ & $\begin{array}{l}\text { People and procedures for assessing } \\
\text { information needs, developing the needed } \\
\text { information, and helping decision makers } \\
\text { use the information to generate and validate } \\
\text { actionable customer and market insights. }\end{array}$ \\
\hline i E & $\begin{array}{l}\text { Input subsystem (internal accounting, } \\
\text { marketing intelligence, marketing research), } \\
\text { database, output subsystem }\end{array}$ \\
\hline $\begin{array}{l}\text { alv } \\
{[9}\end{array}$ & $\begin{array}{l}\text { Operational sub-system (collection and } \\
\text { accumulation of data, marketing functions), } \\
\text { management sub-system (marketing } \\
\text { information system, marketing research } \\
\text { system, marketing decision support system, } \\
\text { marketing planning system, marketing } \\
\text { control system, marketing reporting system) }\end{array}$ \\
\hline $\begin{array}{ll}\text { Cox } & \text { D.F., } \\
\text { Good } & \text { R.E. } \\
{[3]} & \end{array}$ & 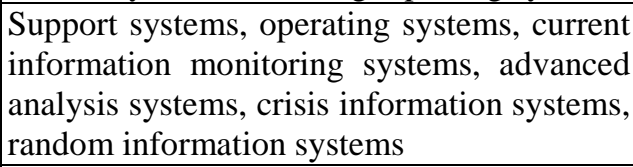 \\
\hline . [4] & $\begin{array}{l}\text { system, mo } \\
\mathrm{n}\end{array}$ \\
\hline R.A. & 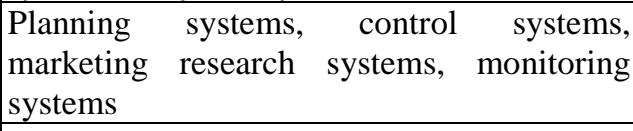 \\
\hline lia R.S. & $\begin{array}{l}\text { optimization models, } \\
\text { ses }\end{array}$ \\
\hline $\begin{array}{l}\text { López- } \\
\text { Bonilla } \\
\text { J.M., } \\
\text { López- } \\
\text { Bonilla } \\
\text { L.M., Peña- } \\
\text { Vinces J.C. } \\
\text { [10] }\end{array}$ & $\begin{array}{l}\text { Database connects two sections. The first } \\
\text { section includes the collection of the } \\
\text { organization's internal and external data } \\
\text { through three subsystems (internal } \\
\text { registration, research, and intelligence; the } \\
\text { second section is focused on the optimal } \\
\text { transformation of data into truthful, relevant, } \\
\text { and appropriate information for managerial } \\
\text { purposes }\end{array}$ \\
\hline
\end{tabular}

Table 3: Functions performed by MkIS components at different stages of DAIMID process

\begin{tabular}{|c|c|c|c|c|c|}
\hline \multirow{2}{*}{ Stage } & \multicolumn{5}{|c|}{ MkIS component } \\
\hline & 1 & 2 & 3 & 4 & 5 \\
\hline $\begin{array}{l}\text { The problem diagnostics } \\
\text { (identification) }\end{array}$ & $\begin{array}{l}\text { F3, } \\
\text { F7 }\end{array}$ & $\mathrm{F} 2$ & $\begin{array}{l}\text { F1 } \\
\text { F5 }\end{array}$ & $\begin{array}{l}\text { F1, } \\
\text { F6 }\end{array}$ & $\mathrm{F} 1$ \\
\hline The problem analysis & $\begin{array}{l}\mathrm{F} 3 \\
\mathrm{~F} 7\end{array}$ & $\mathrm{~F} 2$ & $\mathrm{~F} 1$ & $\mathrm{~F} 1$ & $\mathrm{~F} 1$ \\
\hline $\begin{array}{|ll|}\text { MID } & \text { alternatives } \\
\text { development } & \\
\end{array}$ & $\begin{array}{l}\text { F3 } \\
\text { F7 }\end{array}$ & $\begin{array}{l}\mathrm{F} 2, \\
\mathrm{~F} 4\end{array}$ & $\mathrm{~F} 1$ & $\mathrm{~F} 1$ & $\mathrm{~F} 1$ \\
\hline \begin{tabular}{|lll}
$\begin{array}{l}\text { Streamlining of } \\
\text { alternatives }\end{array}$ & & \\
\end{tabular} & $\begin{array}{l}\text { F3 } \\
\text { F7 }\end{array}$ & $\begin{array}{l}\mathrm{F} 2, \\
\mathrm{~F} 4\end{array}$ & $\mathrm{~F} 1$ & $\mathrm{~F} 1$ & $\mathrm{~F} 1$ \\
\hline $\begin{array}{llr}\text { Defining criteria for } \\
\text { evaluating }\end{array}$ & $\begin{array}{l}\text { F3 } \\
\text { F7 }\end{array}$ & $\mathrm{F} 2$ & $\mathrm{~F} 1$ & $\mathrm{~F} 1$ & $\mathrm{~F} 1$ \\
\hline $\begin{array}{l}\text { Comparison of alternatives } \\
\text { and selection of particular } \\
\text { MID }\end{array}$ & $\begin{array}{l}\text { F3 } \\
\text { F7 }\end{array}$ & $\begin{array}{l}\mathrm{F} 2 \\
\mathrm{~F} 4\end{array}$ & $\mathrm{~F} 1$ & $\mathrm{~F} 1$ & $\mathrm{~F} 1$ \\
\hline MID implementation & $\begin{array}{l}\mathrm{F} 3 \\
\mathrm{~F} 7\end{array}$ & - & $\begin{array}{l}\text { F1, } \\
\text { F5 }\end{array}$ & $\begin{array}{l}\text { F1, } \\
\text { F6 }\end{array}$ & - \\
\hline $\begin{array}{l}\text { Analysis and control of } \\
\text { MID implementation }\end{array}$ & $\begin{array}{l}\text { F3, } \\
\text { F7 }\end{array}$ & $\begin{array}{l}\mathrm{F} 2, \\
\mathrm{~F} 4\end{array}$ & $\begin{array}{l}\text { F1, } \\
\text { F5 }\end{array}$ & $\begin{array}{l}\text { F1, } \\
\text { F6 }\end{array}$ & - \\
\hline $\begin{array}{l}\text { Correction of deviations } \\
\text { and discrepancies }\end{array}$ & $\begin{array}{l}\text { F3 } \\
\text { F7 }\end{array}$ & - & $\begin{array}{l}\text { F1, } \\
\text { F5 }\end{array}$ & $\begin{array}{l}\text { F1, } \\
\text { F6 }\end{array}$ & - \\
\hline
\end{tabular}

Note. 1 - database; 2 - marketing information analysis system; 3 - internal current monitoring subsystem; 4 external current monitoring subsystem; 5 - marketing research subsystem. 


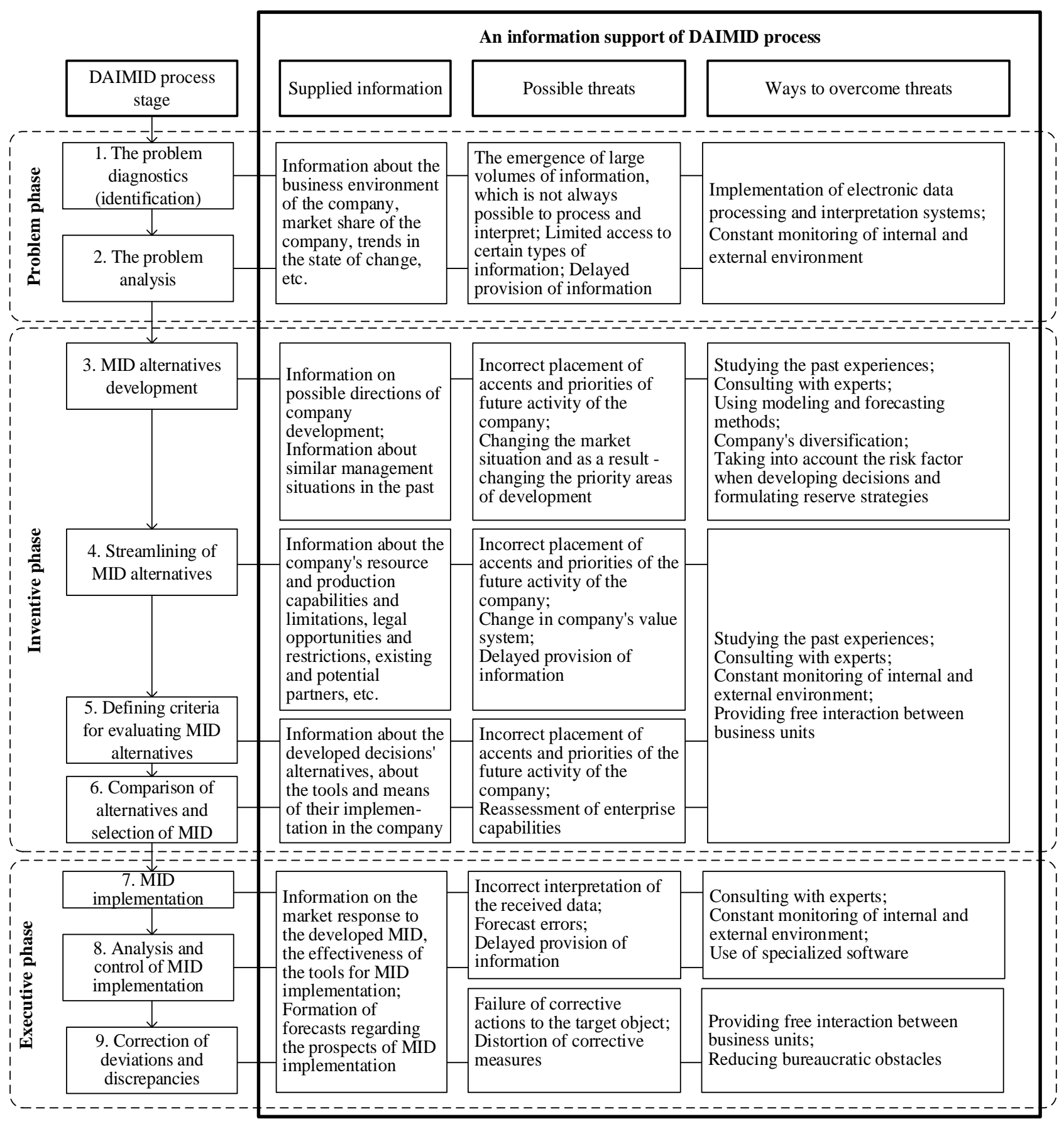

Fig. 2. Information flows in DIAMID process Source: Author's development

\section{CONCLUSION}

Summarizing the above, it can be noted that the authors have developed the principles of forming an information support system for marketing innovative decisions in Ukrainian companies. Namely, functions, marketing information system structure and its components interactions, sequence and content of stages of MID development and creation, information flows interactions scheme. The role of marketing information system in market-oriented activities of a modern companies is outlined. Prospects and problems of introduction of marketing information systems Ukrainian companies are defined and systematized.

The research results develop the theoretical and practical principles of innovation management in terms of increasing the level of information support for marketing innovative decisions in companies. Practical implementation of research results will increase the effectiveness of innovative decisions and companies' marketing activities, which, subsequently, will increase their competitiveness and strengthen market positions.

Further research should focus on improving the methodological tools for supporting marketing innovative decisions.
Blue Eyes Intelligence Engineering \& Sciences Publication 


\section{ACKNOWLEDGMENT}

The paper was written according to budget money from the Ministry of Education and Science in Ukraine, given to develop research topics: № SR 0118U003572 "The development of a mechanism of commercialization of innovative products"; № SR 0117 U003928 “The mechanism of management of the formation of strategies of outstripping innovative development of industrial enterprises"; № SR 0119U100179 "Development of scientific and methodological foundations and practical tools for evaluating of the product innovations commercial (market) prospects".

\section{REFERENCES}

1. Kotler Ph., Armstrong G. (2012). Principles of marketing. $14^{\text {th }}$ edition. Pearson Prentice Hall. 744 p.

2. Balatskyi O.F. et al. (2006). Economic potential of administrative and production systems: Monograph [Ekonomicheskii potencial administrativnykh I proizvodstvennykh system: Monographiya]. Pulishing company "University Book". $973 \mathrm{p}$.

3. Cox D. F., Good R.E. (1967). How to build a marketing information system. Harvard Business Review. Vol. 45. No. 3 (May-June). pp. 145-154.

4. Graf F. (1979). Information systems for marketing. Marketing trends. Vol. 2. pp. 1-3.

5. Li E. Y. (1995). Marketing information systems in the top U.S. companies : a longitudinal analysis. Information and management. No. 28 (1). pp. 13-31.

6. Proctor R. A. (1991). Marketing information systems. Management decisions. Vol. 29. No. 4. pp. 55-60.

7. Samli A. Coskun (1996). Information-driven marketing decisions: development of strategic information systems. Preager Publishers, $216 \mathrm{p}$.

8. Sisodia R. S. (1992). Marketing information and decision support systems for services. The Journal of Services Marketing. Vol. 6. No. 1. p. 51-64.

9. Talvinen J. M. (1995). Information systems in marketing: Identifying opportunities for new applications. European Journal of Marketing. Vol. 29. No. 1. pp. 8-26.

10. López-Bonilla J.M. López-Bonilla, L.M. \& Peña-Vinces, J.C. (2015). Marketing Information Systems: An integrative view. In: Contemporary Issues in Tourism and Management Studies. Santos, JA et al editors. Algarve, Portugal

11. Daneshjo Naqibullah, Kravec Michal (2014). Sources of marketing information system. International journal of interdisciplinary in theory and practice, № 5, pp. 22-24.

12. Hakimpoor H., Khairabadi M. (2018). Management Information Systems, Conceptual Dimensions of Information Quality and Quality of Managerial Decisions: Modelling Artificial Neural Networks. Universal Journal of Management, 6(4), pp. 127-133.

13. Laudon, K.C., Laudon, J.P. (2014). Management information systems. Managing the digital firm. Thirteenth edition. Global edition. Pearson Education Limited. 648 p.

14. Al-Mamary, Y.H., Shamsuddin, A., \& Aziati, N. (2013). The Impact of Management Information Systems Adoption in Managerial Decision Making: A Review. Management Information Systems, Vol. 8, No. 4, pp. 010-017.

15. Abrego-Almazán, D., Sánchez Tovar, Y., Medina Quintero, J. (2017). Influence of information systems in organizational performance. Contaduría y Administración, 62, pp. 321-338.

16. European Comission. Eurostat. Official website. Retrieved from https://ec.europa.eu/eurostat/

17. Mas M., Fernández de Guevara J., Robledo J.C.,
López-Cobo M., The 2017 PREDICT Key Facts Report. An Analysis of ICT R\&D in the EU and Beyond, EUR 28594 EN, doi:10.2760/397817

18. State Statistics Service of Ukraine. Official website. Retrieved from http://www.ukrstat.gov.ua/

\section{AUTHORS PROFILE}

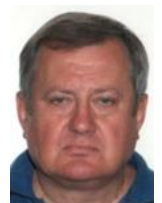

Illiashenko Sergii, Doctor of Economics, Department of Management of Innovative Entrepreneurship and International Economic Relations, National Technical University "Kharkiv Polytechnic Institute", Kharkiv, Ukraine; Department of Marketing, University of Economics and Humanities, Bielsko-Biala, Poland.

Research interests: innovative management, marketing of innovations, digital marketing, knowledge management

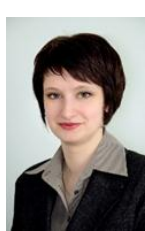

Shypulina Yuliia, Doctor of Economics, Department of Economic Cybernetics and Marketing Management, National Technical University "Kharkiv Polytechnic Institute", Kharkiv, Ukraine.

Research interests: innovative management, management of innovative culture of enterprises, innovations in marketing

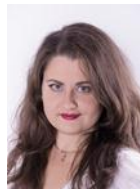

Gryshchenko Olena, Ph.D., Department of Business Economics and Administration, Sumy State Pedagogical University, Sumy, Ukraine.

Research interests: innovative management, decision making, strategic management

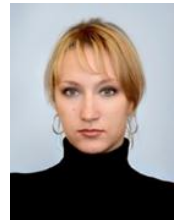

Illiashenko Nataliia, Ph.D., Department of Economic Cybernetics and Marketing Management, National Technical University "Kharkiv Polytechnic Institute", Kharkiv, Ukraine.

Research interests: marketing of innovations, strategic management of enterprises, innovative management 